\title{
Initial Development in Joining of ODS Alloys Using Friction Stir Welding
}

Zhili Feng and Weiju Ren

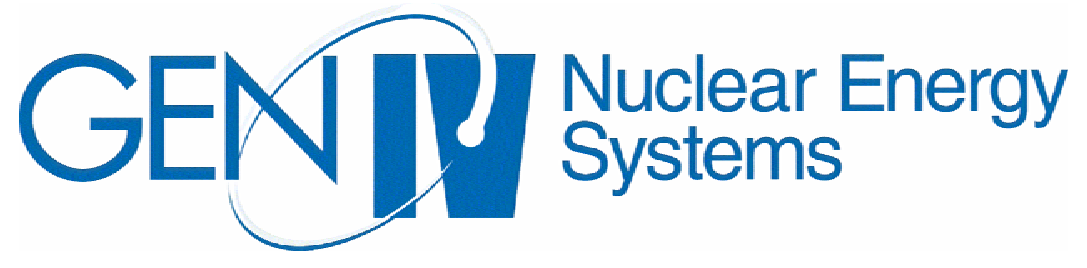

August 15, 2006

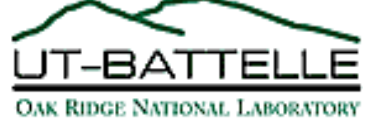


This report was prepared as an account of work sponsored by an agency of the United States Government. Neither the United States government nor any agency thereof, nor any of their employees, makes any warranty, express or implied, or assumes any legal liability or responsibility for the accuracy, completeness, or usefulness of any information, apparatus, product, or process disclosed, or represents that its use would not infringe privately owned rights. Reference herein to any specific commercial product, process, or service by trade name, trademark, manufacturer, or otherwise, does not necessarily constitute or imply its endorsement, recommendation, or favoring by the United States Government or any agency thereof. The views and opinions of authors expressed herein do not necessarily state or reflect those of the United States Government or any agency thereof. 


\section{Initial Development in Joining of ODS Alloys Using Friction Stir Welding}

Zhili Feng and Weiju Ren

August 15, 2006

Prepared for

Office of Nuclear Energy

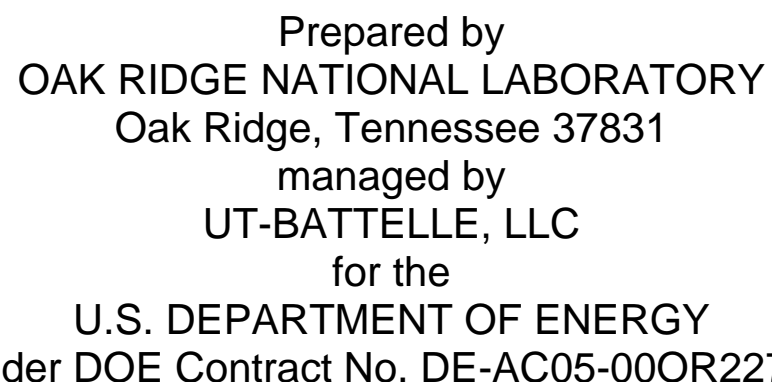

Under DOE Contract No. DE-AC05-00OR22725 


\begin{abstract}
ABTRACT
Solid-state welding of oxide-dispersion-strengthened (ODS) alloy MA956 sheets using friction stir welding (FSW) was investigated. Butt weld was successfully produced. The weld and base metals were characterized using optical microscopy, scanning electronic microscopy, transmission electronic microscopy, and energy dispersion x-ray spectrum. Microhardness mapping was also conducted over the weld region. Analyses indicate that the distribution of the strengthening oxides was preserved in the weld. Decrease in microhardness of the weld was observed but was insignificant. The preliminary results seem to confirm the envisioned feasibility of FSW application to ODS alloy joining. For application to Gen IV nuclear reactor heat exchanger, further investigation is suggested.
\end{abstract}




\section{CONTENTS}

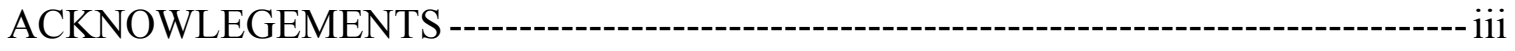

1. INTRODUCTION -- 1

2. MATERIAL ----_- 5

3. WELDING--- 6

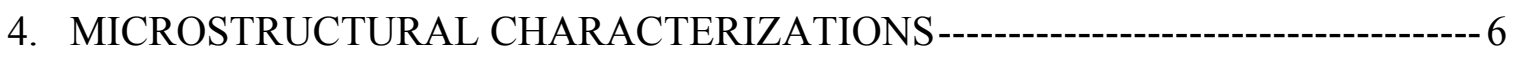

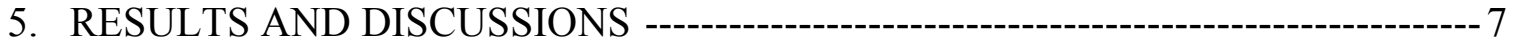

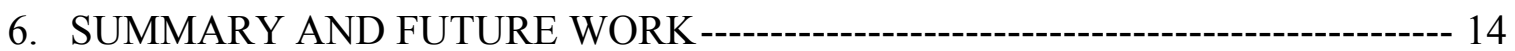

7. REFERENCES --- 15 


\section{ACKNOWLEDEMENTS}

The authors are grateful to William Corwin for programmatic direction, support, and constructive comments to this innovative research; to Joe Horton, Stan David, Hanbing $\mathrm{Xu}$ and Oleg Barabash for microstructural analysis support.

This work is sponsored by the U.S. Department of Energy, Office of Nuclear Energy Science and Technology under contract DE-AC05-00OR22725 with Oak Ridge National Laboratory, managed by UT-Battelle, LLC. 


\section{INTRODUCTION}

The ever increasing demand for higher efficiency in power generation has provided a driving force for energy systems to operate at increasingly higher temperatures. In the development of the Gen IV nuclear reactors, the operation temperature of the Very High Temperature Reactor (VHTR) concept will be up to $950^{\circ} \mathrm{C}$ with a design life of 60 years. The combination of such high temperature and long service life has posed a great challenge to metallic structural materials for the reactor construction. Conventional high-temperature alloys are strengthened mainly by solid solution and precipitation mechanisms that hinder dislocation movements. As the desired service temperatures become increasingly higher and lives significantly longer, these alloys can eventually lose their strength as the precipitates become dissolved or coarsened, and the solid solute atoms become highly diffusive due to the greatly increased thermal agitation. The oxide dispersion strengthened (ODS) alloys, on the other hand, derives its high temperature strength mainly from a fine dispersion of oxides that are nearly insoluble in the matrix. This insolubility enables the oxide particles to hinder dislocation movements and thus retain strength up to temperatures near the matrix melting point. Furthermore, unlike precipitation strengthening, which requires high solubility of solute atoms at high temperatures and vise versa, confining its viability to a relatively small range of matrix selections, the ODS mechanism is free from this temperature-solubility requirement, therefore applicable to a broad variety of matrix choices. This freedom provides more alternatives for tailoring the matrix composition to improve corrosion resistance, which is another crucial requirement for high temperature services. Because of these advantages in high temperature, long-time service and corrosion resistance, the ODS alloys have tremendous potentials in satisfying the unprecedented requirements that other metallic materials can not meet in Gen IV nuclear reactor applications, especially in the intermediate heat exchanger where molten salt is considered as the coolant in the secondary circuit. The excellent high temperature strength and corrosion resistance of the ODS alloys have also been drawing great interests from many other industries [1-8].

However, the ODS alloys have their own great disadvantage in joining. Because the strengthening oxide particles can only be "mechanically alloyed" into the metallic matrix through powder metallurgy, bulk melting in fusion welding inevitably destroys the fine particle distribution by causing particle aggregation as they are rejected at the solidification front in weld pool, thus resulting in substantial decrease in high temperature strength of the weld. Moreover, most ODS alloys have a highly alloyed matrix, which per se are very difficult, if not impossible, to fusion weld. Because fusion welding processes are considered as the primary joining technique in manufacturing high temperature components, the poor fusion weldability has been the major technical bottleneck limiting the application of the entire ODS alloy family. A literature survey indicates that among the fusion welding technologies investigated, few have been successful without significantly reducing the creep resistance of the ODS alloy. It was reported that ODS alloy MA956 joints processed by tungsten inert gas welding (TIG) had a 60 $80 \%$ decrease in high temperature strength compared to the base metal [9]; and such reduction mainly resulted from the aggregation of oxide particle and destruction of the original coarse grain. To avoid the aggregation, technique with high energy density such as laser welding was investigated to minimize the weld fusion zone, but aggregation and significant strength reduction were still observed [10 - 11]. Solid-state welding techniques, such as rotary friction welding [1214], diffusion welding [15-25], pulsed electric current sintering bonding [26], brazing [27-34], 
explosive welding [35], and resistance welding [36] were tested with certain degree of success. However, these welding techniques have their own serious drawbacks ranging from limited applicable workpiece size to low joint strength. For example, the rotary friction welding, one of the most promising techniques for joining the ODS alloys, is limited to welding small, cylindrical parts, and can not be employed for large diameter tubing, let alone various forms of linear plate joints, which are very common joint configurations in many high temperature structures. Furthermore, the high pressure applied to the joint region during the welding process causes significant localized plastic deformation, squeezes out the material, and forms small recrystallized grains, which are detrimental to the creep strength. Clearly, more adequate welding techniques must be developed to preserve the unique oxide dispersion strengthening mechanism in the weld before the ODS alloy family can be used to its full capacity in high temperature services.

The Friction Stir Welding (FSW) is an innovative solid-state joining process invented in the early 1990's [37]. Considered as one of the most significant welding inventions in the last two decades, the FSW enables the advantages of solid-state joining for fabrication of continuous linear welds without bulk melting [38]. The basic principles of the FSW are illustrated in Fig. 1. The key component is a rotating tool composed of a shoulder and a profiled pin extending along the axis of rotation. The shoulder is the working surface normal to the axis of rotation. Once the workpiece is properly fixed, the tool is rotated at high speeds to plunge its pin into the workpiece joint line and make full contact between the shoulder and the workpiece. Then, the tool travels along the joint line, rotating with a pressure to maintain the full contact. As illustrated in Fig. 1b, the temperature in the cylindrical volume of workpiece material under the rotating tool is increased substantially, largely due to frictional heating between the rotating tool and the workpiece. The increase in temperature softens the material without melting, and allows the rotating tool to mechanically stir the softened material flowing to the backside of the pin where it is consolidated to form a metallurgical bond [39].

Because the FSW creates weld joints without bulk melting, it is envisioned that the aggregation of the oxide particles can be eliminated if this technique is properly adapted for joining the ODS alloy; and oxide-dispersion-strengthened welds can thus be developed with preserved excellent high temperature properties. Furthermore, the capability to create continuous linear welds enables FSW to weld plates (Fig. 2) as well as large diameter piping (Fig. 3), a task no other solid-state welding techniques are suitable, but commonly required in manufacturing high temperature components. Based on these expectations and technical analyses, Ren proposed to investigate the joining of ODS alloys using FSW technology. A proposal was later developed with detailed research plans in collaboration with Feng in 2004 [40]. Funding was provided by the Gen IV Materials Program for initial studies in FY06. Progress in the preliminary investigation has been very promising, and the results are presented in this report. 


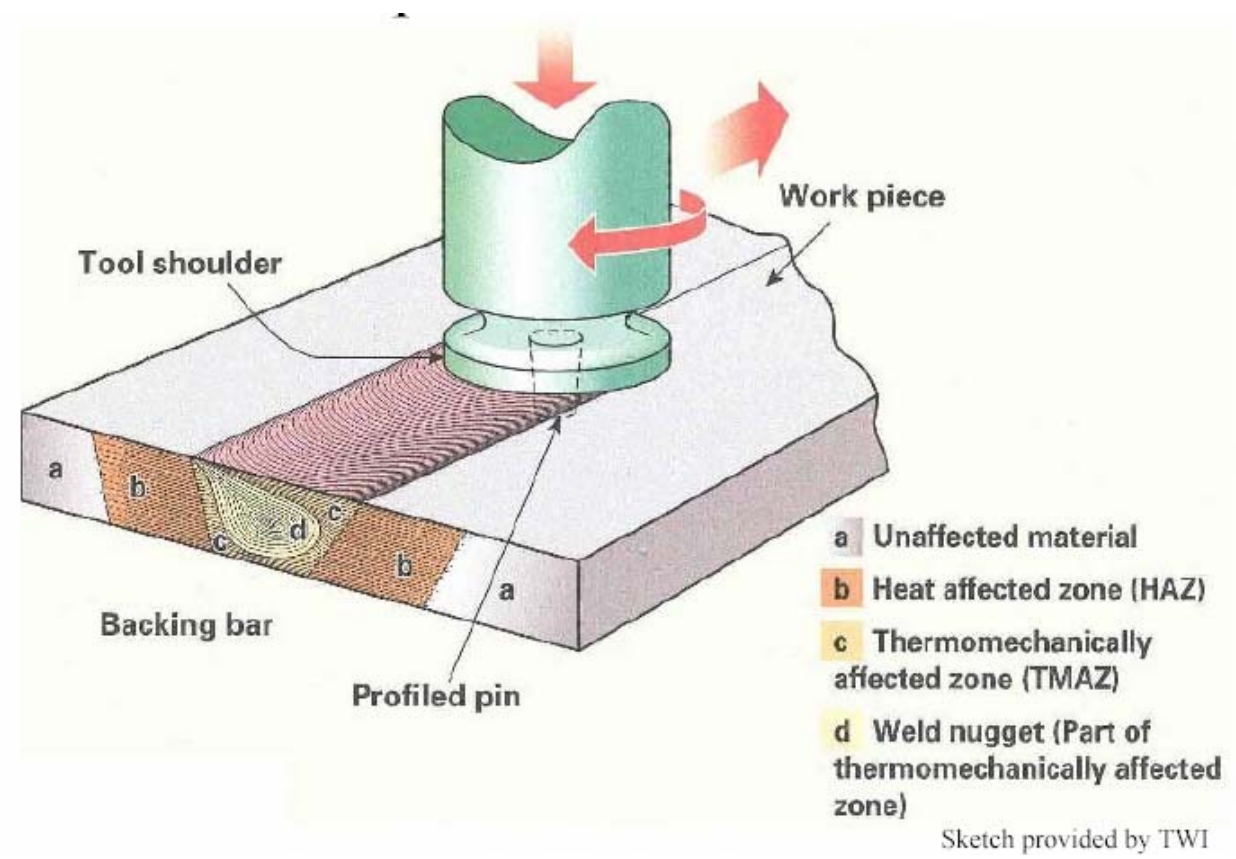

(a)

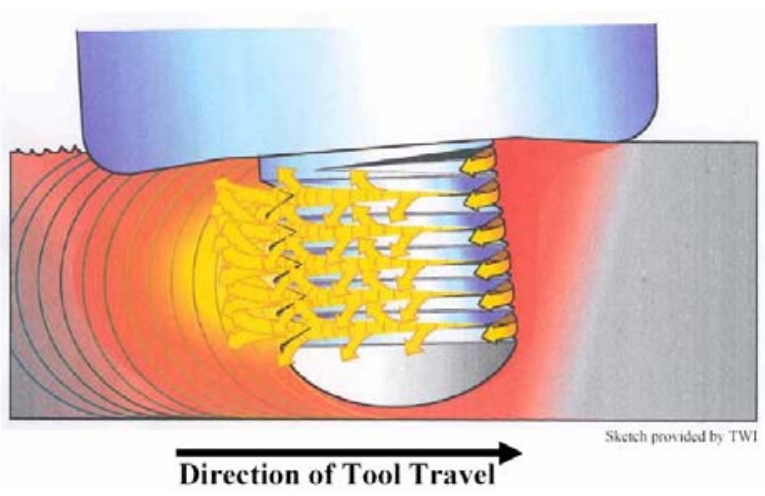

(b)

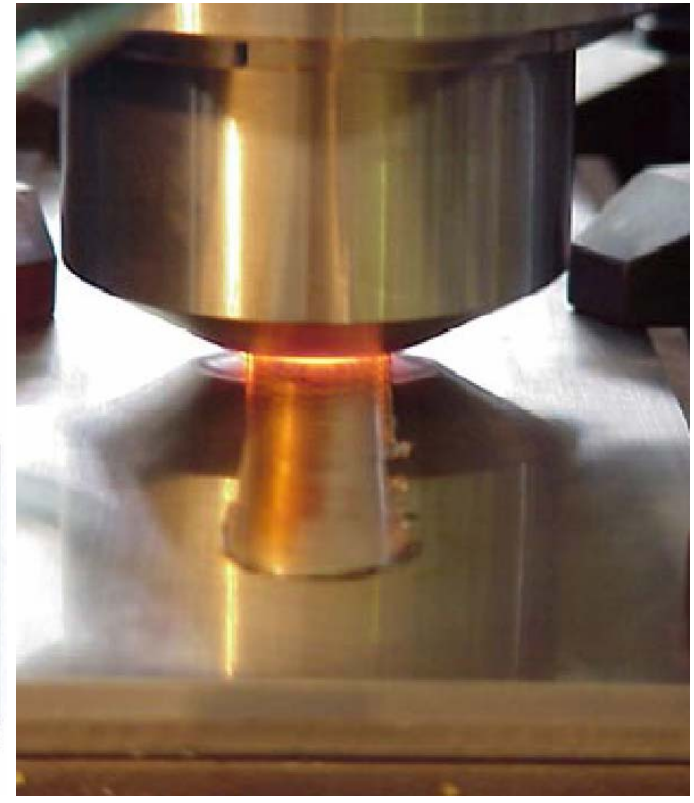

(c)

Fig. 1: Schematics of Friction Stir Welding Process: (a) Overview of the process shows the position of the tool relative to the workpiece being welded; (b) Sectional view along the butting plane of the workpiece illustrates the material flow under the stirring action of the pin. The red region illustrates the softened material region; (c) FSW in action during welding of austenitic stainless steel alloy 


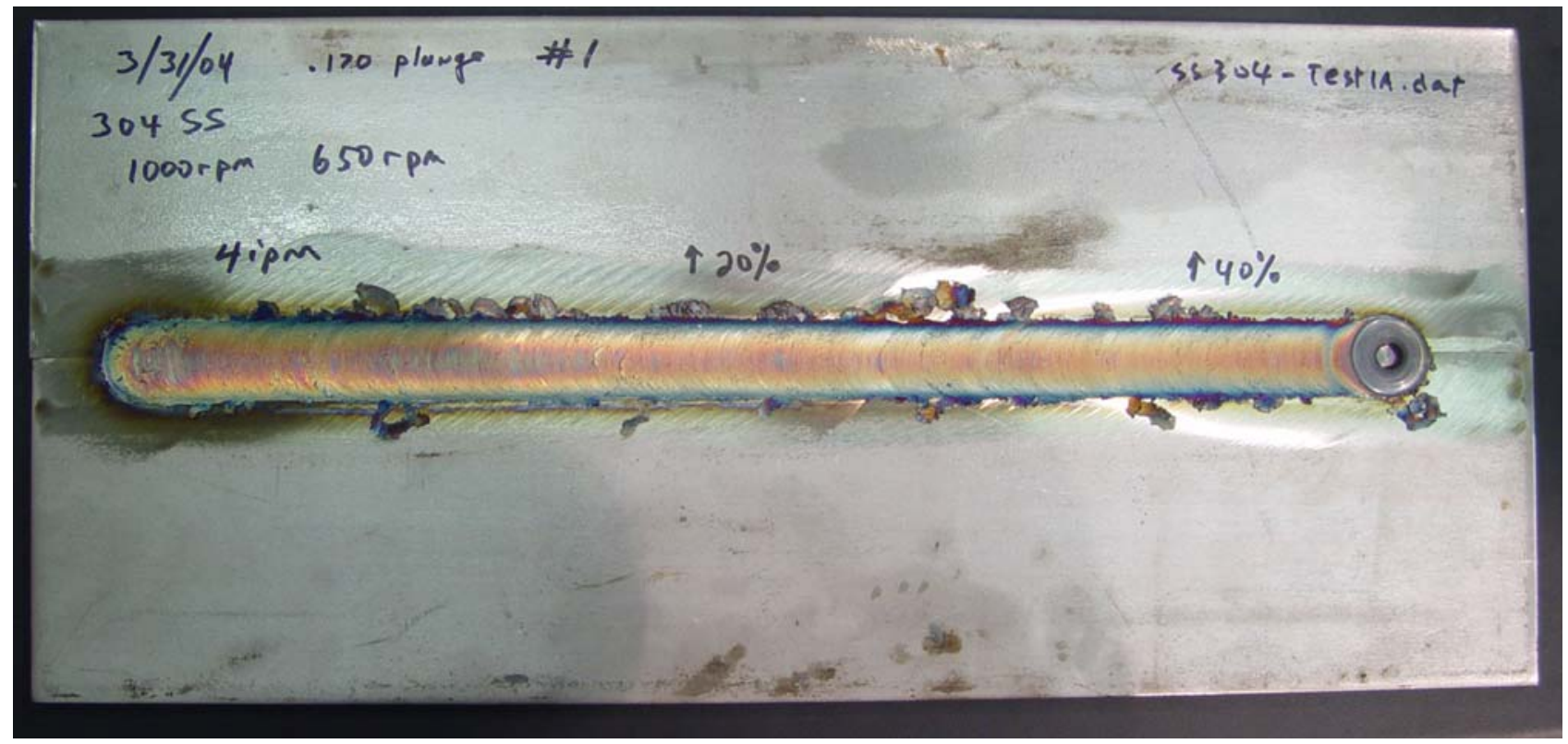

Fig. 2: Friction stir weld of stainless steel 304 plates, developed by ORNL

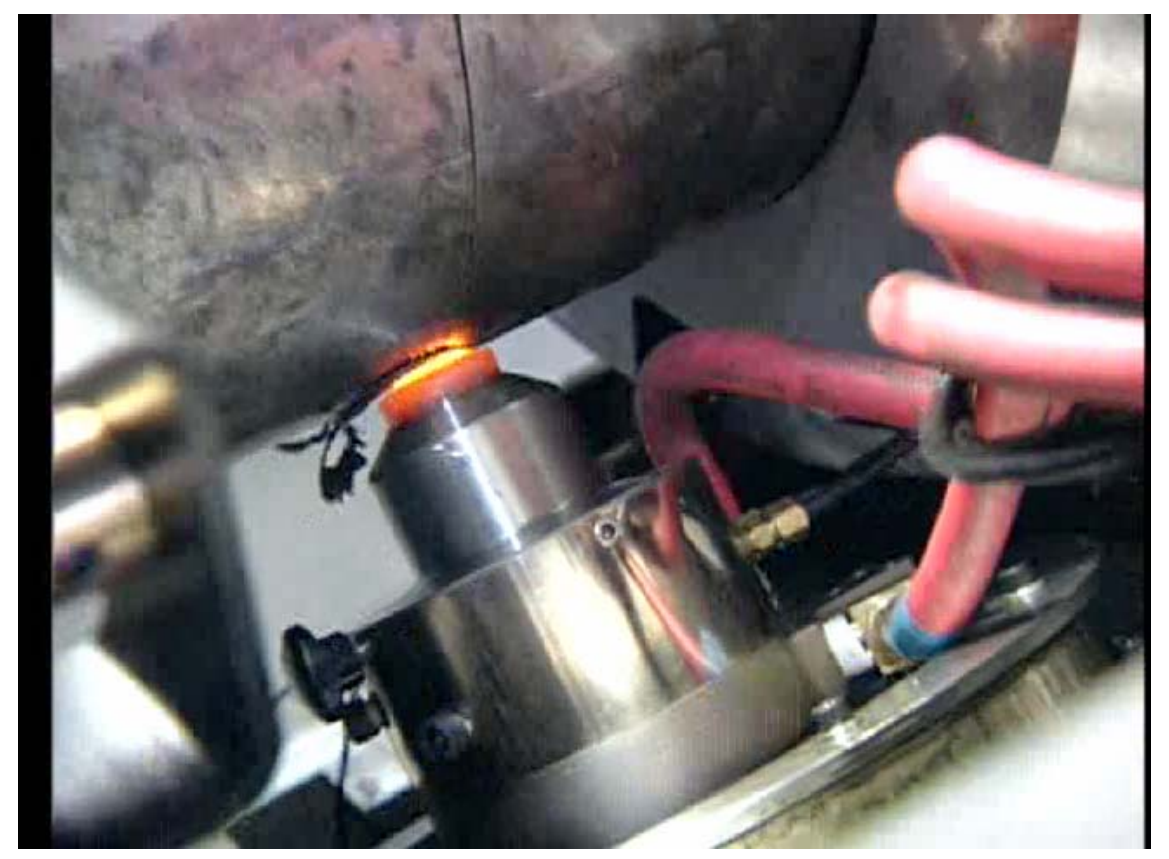

Fig. 3: A prototype FSW system for steel piping welding, developed by MegaStir 


\section{MATERIAL}

The ODS alloy employed in this investigation is Incoloy Alloy MA956, an iron base ODS ferritic stainless steel with a high level of aluminum for improved corrosion and oxidation resistance. The composition of alloy MA956 is presented in Table 1 [41]. Compared to nickel base alloys, the iron base MA956 has lower density, higher melting point and lower coefficient of thermal expansion. The MA956 is manufactured by mechanical alloying process with uniform distribution of extremely fine yttrium oxide dispersion particles. The combination of high aspect ratio grain structure and ultra fine yttrium oxides contributes to its excellent mechanical strength at elevated temperatures. Aluminum is added to form adherent thin layer of alumina under oxidizing conditions, which is usually more protective than the chromia film commonly formed on $\mathrm{Ni}-\mathrm{Cr}$ alloys.

Table 1: Composition of ODS Alloy MA956 (wt. \%)

\begin{tabular}{|c|c|c|c|c|c|c|c|c|c|c|c|}
\hline & $\mathbf{F e}$ & $\mathbf{C r}$ & $\mathbf{A l}$ & $\mathbf{T i}$ & $\mathbf{Y}_{\mathbf{2}} \mathbf{O}_{\mathbf{3}}$ & $\mathbf{C}$ & $\mathbf{C u}$ & $\mathbf{M n}$ & $\mathbf{C o}$ & $\mathbf{N i}$ & $\mathbf{P}$ \\
\hline Max & Bal. & 21.5 & 5.75 & 0.6 & 0.7 & 0.1 & 0.15 & 0.30 & 0.3 & 0.5 & 0.02 \\
\hline Min & - & 18.5 & 3.75 & 0.2 & 0.3 & - & - & - & - & - & - \\
\hline
\end{tabular}

Because one of the primary potential applications of ODS alloys in GEN IV nuclear reactor is for the compact heat exchanger, thin sheet MA956 was acquired for the present investigation. The nominal thickness of the sheet material was $1.2 \mathrm{~mm}$. Fig. 4 shows the cross-sectional view of the microstructures in the as-received MA956 sheet. Very large elongated or pancake-shaped grains of high aspect ratio can be observed, which is typical for MA956 sheets after forming and annealing heat treatment to achieve high strength at elevated temperatures [42].

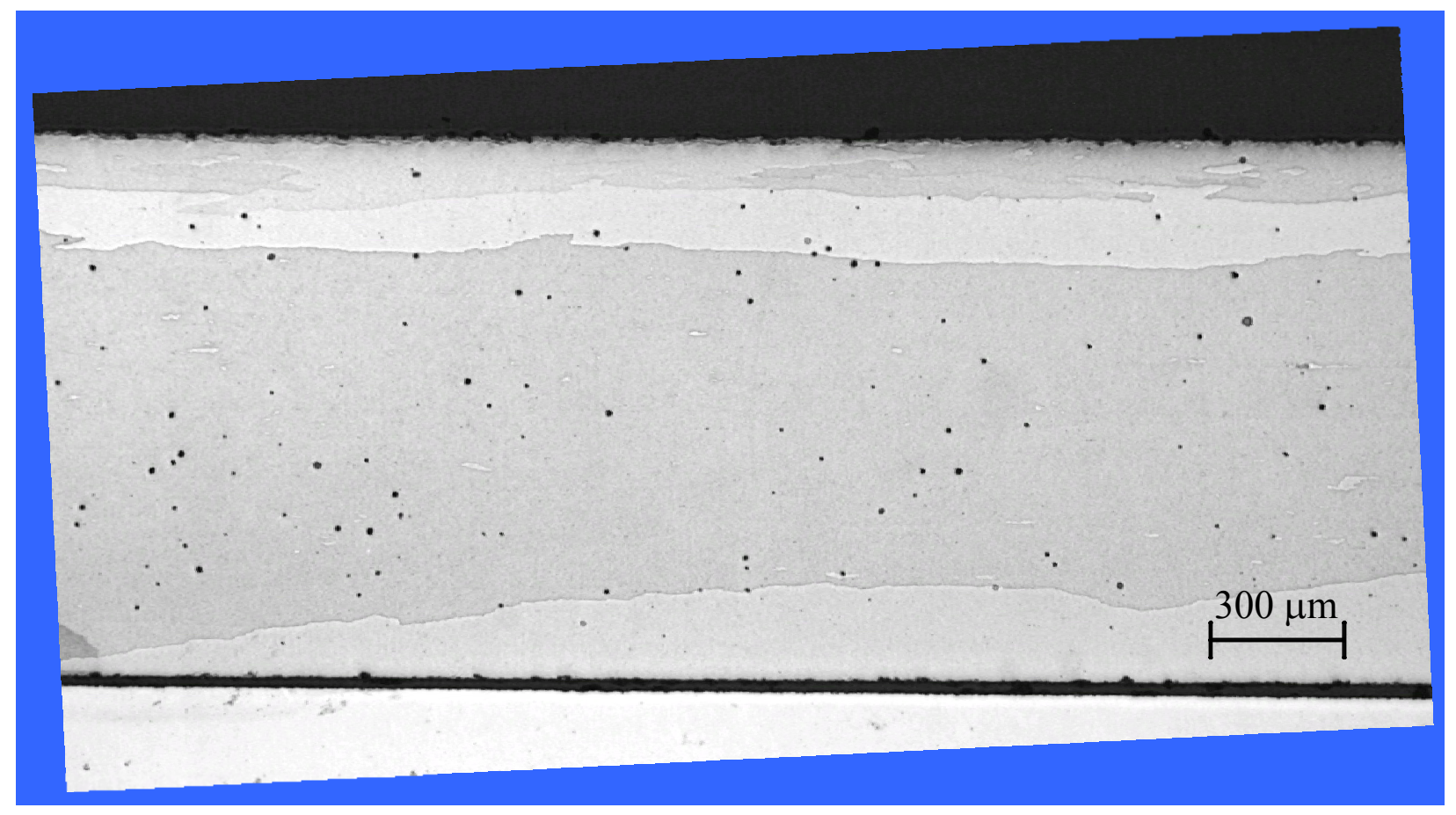

Fig. 4: Large pancake-shaped grains in the as-received MA956 base metal 


\section{WELDING}

In consideration of the heat exchanger fabrication, two types of weld joint configurations, butt joint and lap joint, were investigated. The two weld joints are illustrated in Fig. 5. The butt weld joins two sheets placed side-by-side, whereas the lap weld joins two sheets with one on top of the other. Both welds were supported on an SS304 stainless steel block.

A specially designed pinless tool was used in the welding trials. In this pinless tool design, the friction stir tool only contacts the top surface of the sheet, thus reduce mechanical stirring effect on possible agglomeration of oxide particles.

After several iterations of welding trials, the following welding conditions were used to produce welds for further evaluation: 1000 rpm, $25.4 \mathrm{~mm} / \mathrm{min}$ travel, $12 \mathrm{~mm}$ tool diameter. All welds were made in position control mode on an MTS Intelligent Stir Machine at Oak Ridge National Laboratory (ORNL). The tool was made of Si-based ceramic material. Prior to welding, the surfaces of the MA956 sheets were polished with sand paper to remove surface oxide scale, followed by ethonal cleaning.

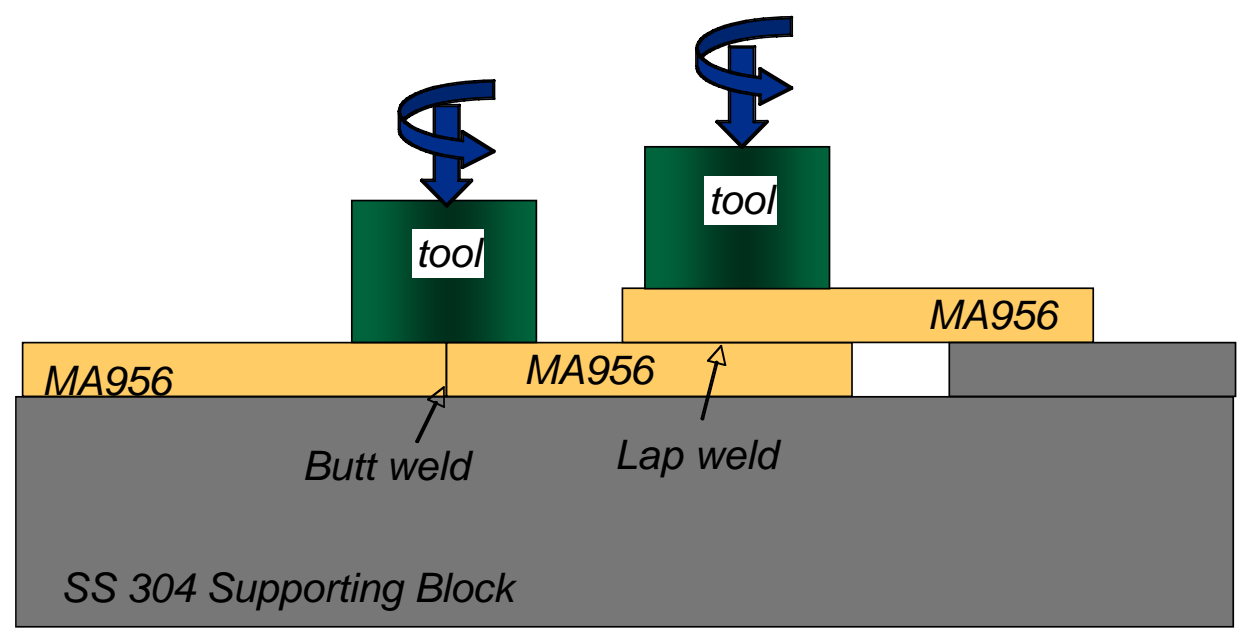

Fig. 5: Butt and lap weld configurations studied in the present investigation

\section{MICROSTRUCTURAL CHARACTERIZATIONS}

The welded samples were examined with optical microscope (OP), scanning electron microscope (SEM), and transmission electron microscope (TEM). In addition, micro-chemistry analyses were performed using energy-dispersive x-ray spectrum (EDS) method to identify particles of various sizes in the stir zone. Microhardness mapping was also conducted to evaluate changes, if any, in material strength in different regions of the welded samples. The metallographic samples were prepared following the standard polishing and etching techniques for ferritic stainless steels. Chemical etching was used for optical metallography, and electroetching was used for SEM. For the TEM specimens, 3-mm diameter disks were cut from the 
weld center. The disks were then processed by mechanical and chemical thinning, followed by twin-jet polishing.

\section{RESULTS AND DISCUSSIONS}

Fig. 6 presents a macro view of the weld cross-section of the butt weld joint. It is obvious that bonding between the two MA956 sheets was achieved. The original interface between the two sheets completely disappeared. It is also noted that the MA956 sheet was bonded to the SS304 substrate, suggesting the feasibility of dissimilar metal bonding between the ferritic MA956 ODS Alloy to the austenitic SS304 stainless steel.

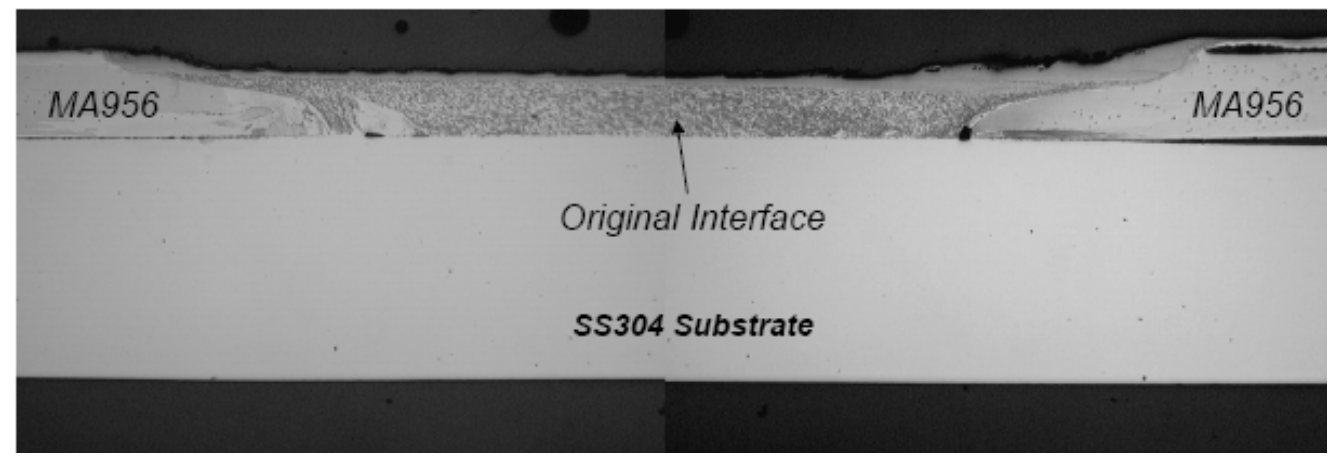

Fig. 6: Cross-section view of the butt weld. SS304 substrate is also shown underneath the weld.

Two distinct regions can be observed in the friction stir welded MA956 sheet as shown in Fig. 7. A thin layer with severe deformation exists in the top surface region of the weld. Underneath is the stir zone consisting of equiaxed recrystallized grains. The transition between the stir zone and the large-grained base metal is quite drastic. Fig. 8 shows the recrystallized grain structures in the two regions at high magnification. The grain size in the stir zone is in the range of 20-40 $\mu \mathrm{m}$. The grains in the surface deformation layer are much smaller, in the range of $5-10 \mu \mathrm{m}$.

\section{Surface deformation layer}

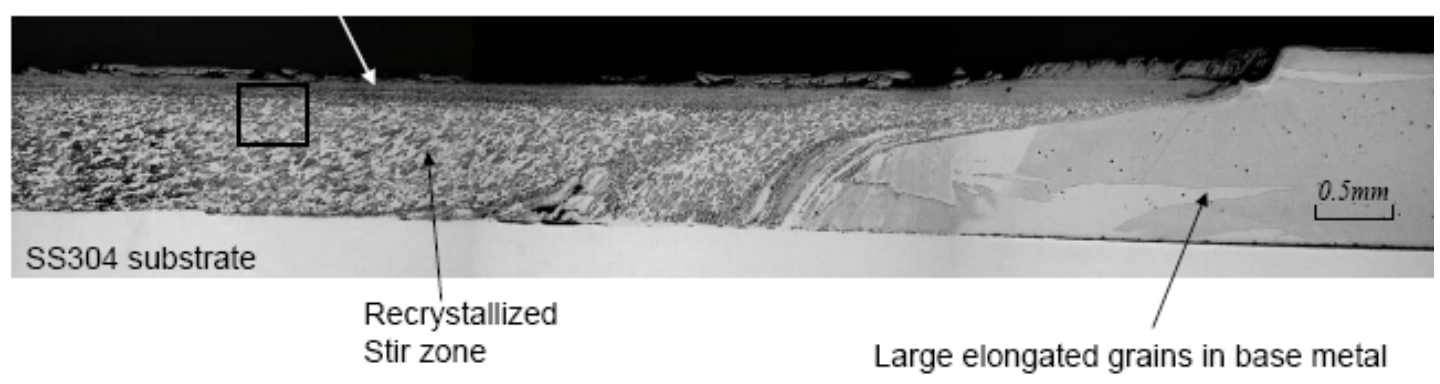

Fig. 7: Two distinct regions in the friction stir weld of MA956. 


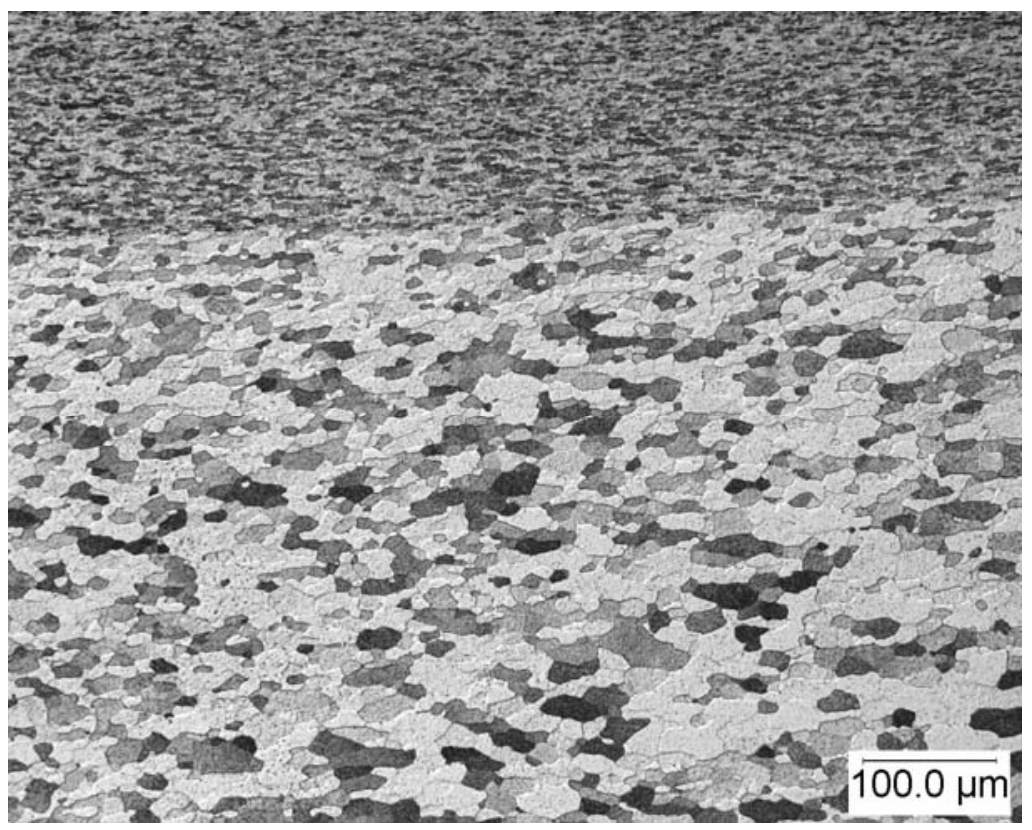

Fig. 8: Recrystallized grains in the stir zone of the butt weld joint, at the location marked by the black rectangle shown in Fig. 7

Fig. 9 shows the lap-joint weld. It can be observed that only partial bonding was achieved using the same process conditions as in the butt-joint weld. Further process development to optimize the welding parameters is apparently needed.

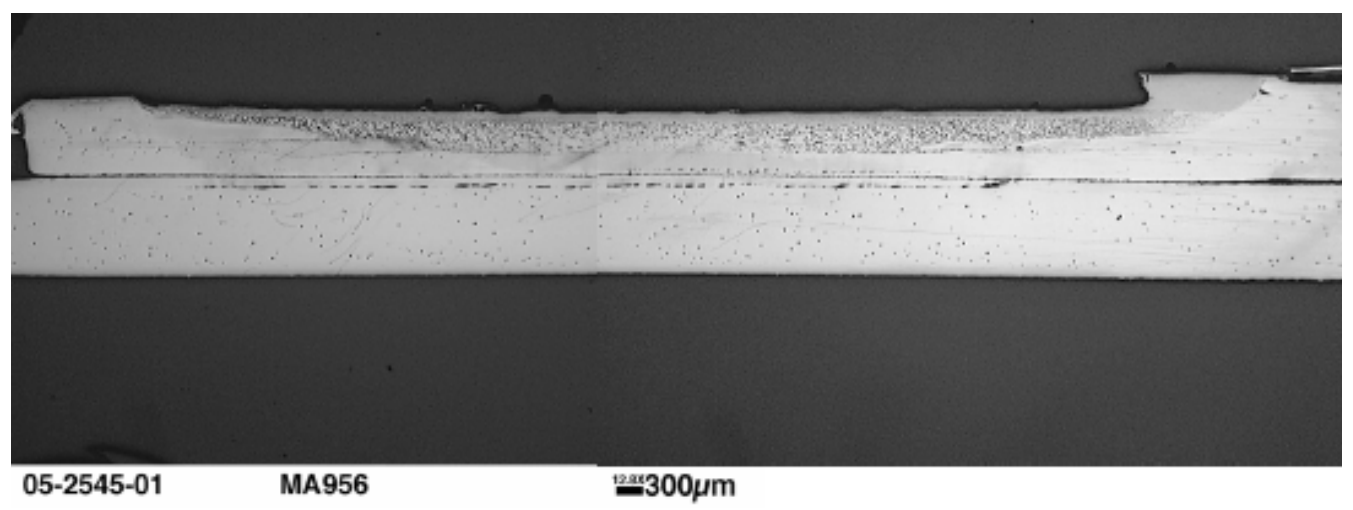

Fig. 9a: Cross-section macro view of the lap weld joint 


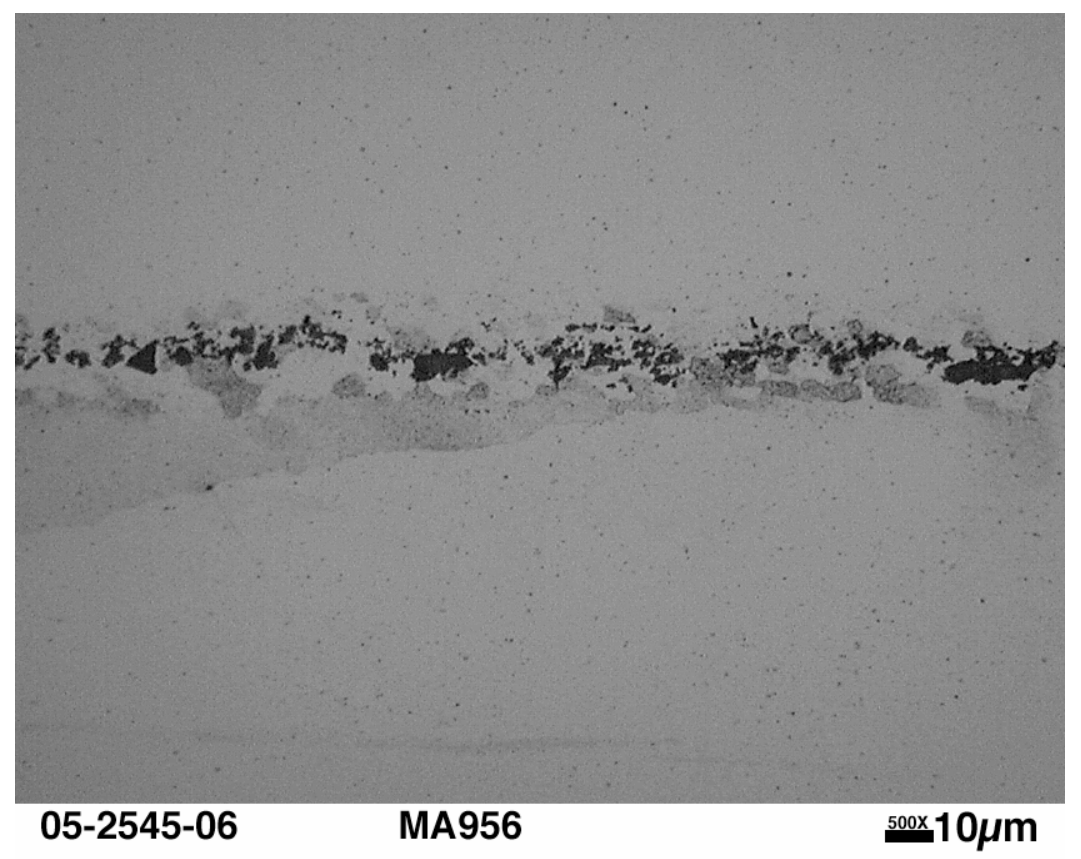

Fig. 9b: Cross-section view of the lap weld joint at high magnification

Oxide particles in the base metal of MA956 can be observed in SEM images, as shown in Fig. 10. The observation in Fig. 10 is consistent with a literature report [43] that two differently sized particles exist in the base metal of MA956. The large particles (ranging from several hundred nanometers to $1 \mu \mathrm{m})$ are reportedly $\mathrm{Al}_{2} \mathrm{O}_{3}$ and $\mathrm{Ti}(\mathrm{C}, \mathrm{N})$; and the smaller particles $(<100$ $\mathrm{nm})$ are yttrium oxide $\left(\mathrm{Y}_{2} \mathrm{O}_{3}\right)$. Often yttrium oxide particles are attached to the larger aluminum oxides.

Fig. 11 presents the distribution of particles in the butt weld (stir zone). It is evident that particles of various sizes are preserved in the weld. There are some indications of particle coarsening in the stir zone as the result of thermomechanical deformation during the friction stir welding process. However, it can be observed in Fig. 11 that the coarsening is very limited, which suggests that the high temperature strengthening mechanisms in ODS alloy MA956 may not be significantly affected.

The stir zone was further analyzed using TEM, and the results are given in Fig. 12. It is apparent that high-angle grain boundaries dominate and the grains are relatively free of dislocations. This suggests that dynamic recrystallization occurred during the friction stir welding of MA956, which is consistent with observations in friction stir welding of other alloy systems. In addition, relatively large amount of particles are preserved within the grains, further suggesting that the friction stir weld may retain high-temperature strength of the ODS base metal. 


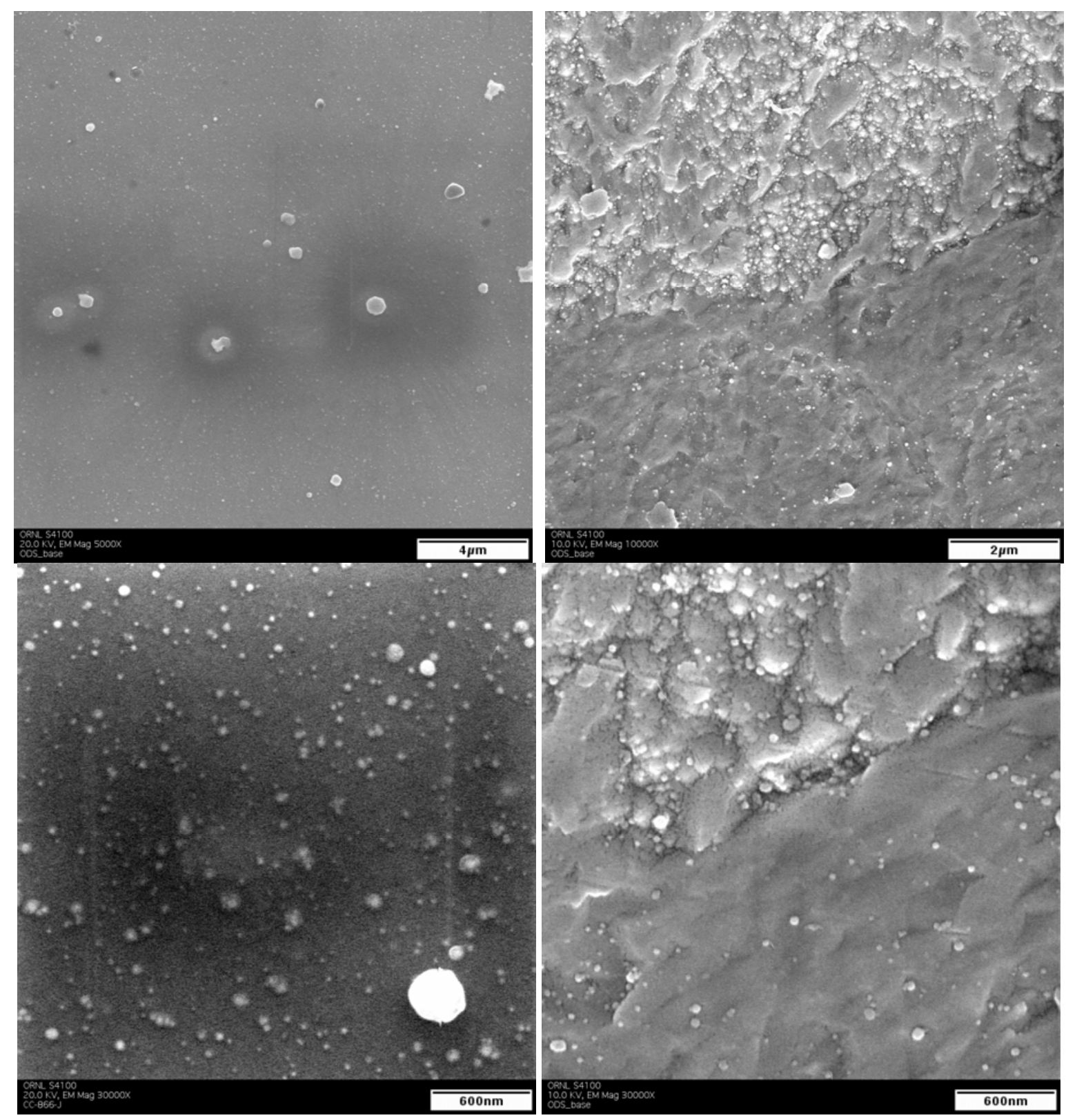

Fig. 10: SEM images of oxide dispersion particles in the base metal

The particles inside the grains in the stir zone were analyzed using EDS to determine the type of the particles as shown in Fig 13. The results are summarized in Table 2 with the measurement locations correspondingly identified in Fig. 14. The determination of the oxygen level is less quantitative due to the overlap with $\mathrm{Fe}$ and other elements peaks. Many of the black particles in Fig. 14 contain a high level of yttrium and oxygen, suggesting they are yttrium oxides. Al-rich particles are also abundant. While standalone yttrium oxide particles exist (\#1, \#8, for example), many of the yttrium particles are attached to Al-rich particles. Further studies are necessary to determine whether the frictions stir welding process would promote such co-habitation of 
INITIAL DEVELOPMENT IN JOINING OF ODS ALLOYS USING FRICTION STIR WELDING

different types of particles, and further, its effects on the high-temperature strength of the friction stir welded joint.
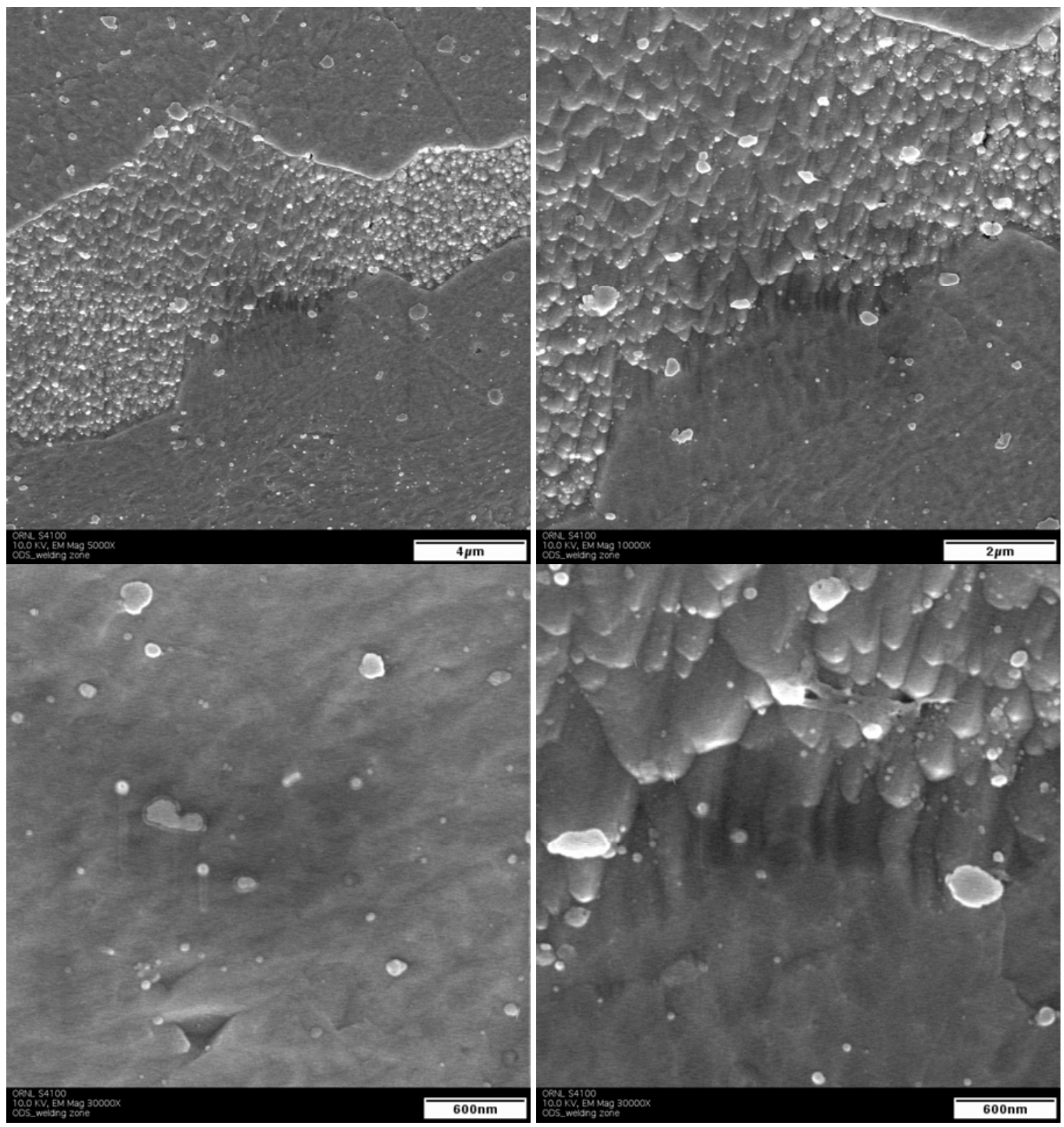

Fig. 11: SEM images of oxide dispersion particles in the stir zone of the butt weld joint 

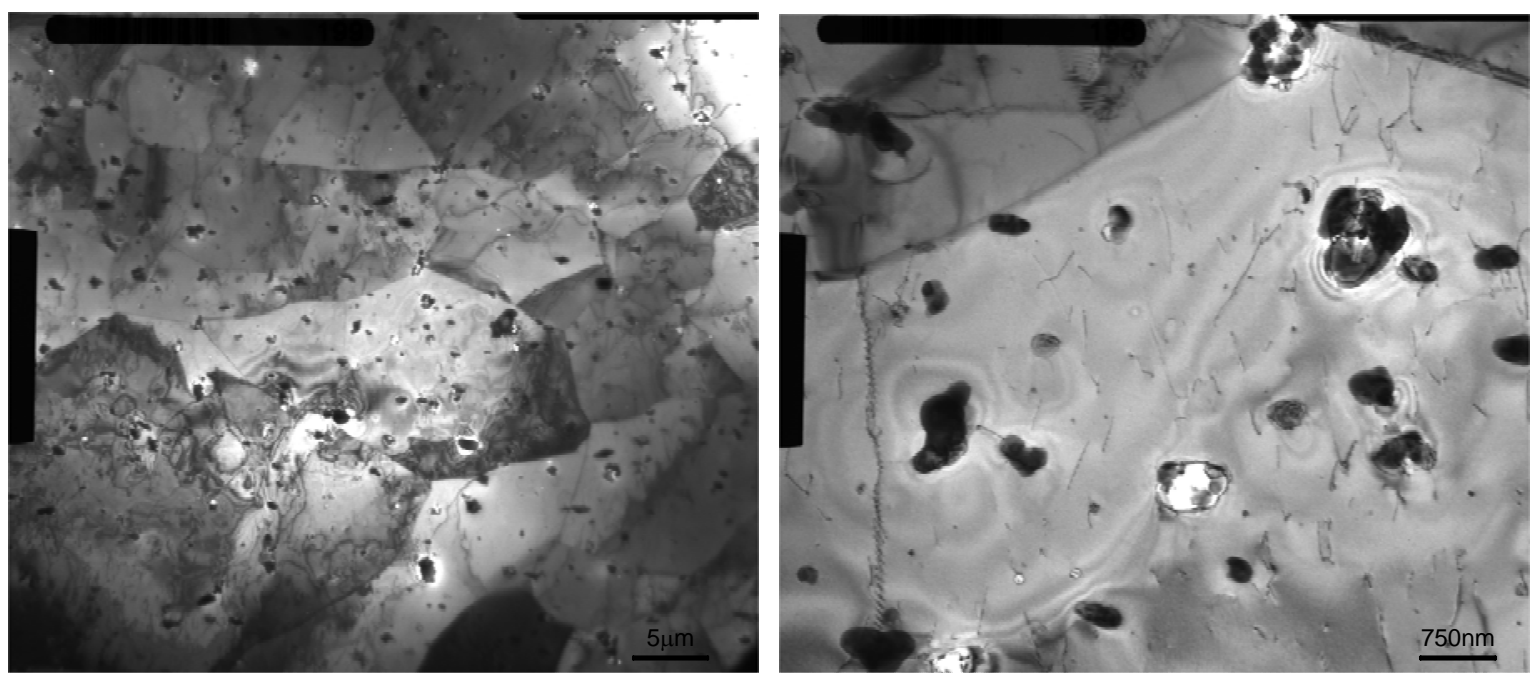

Fig. 12: TEM images showing equiaxed grains and dispersion particles in the stir zone of the butt weld joint.

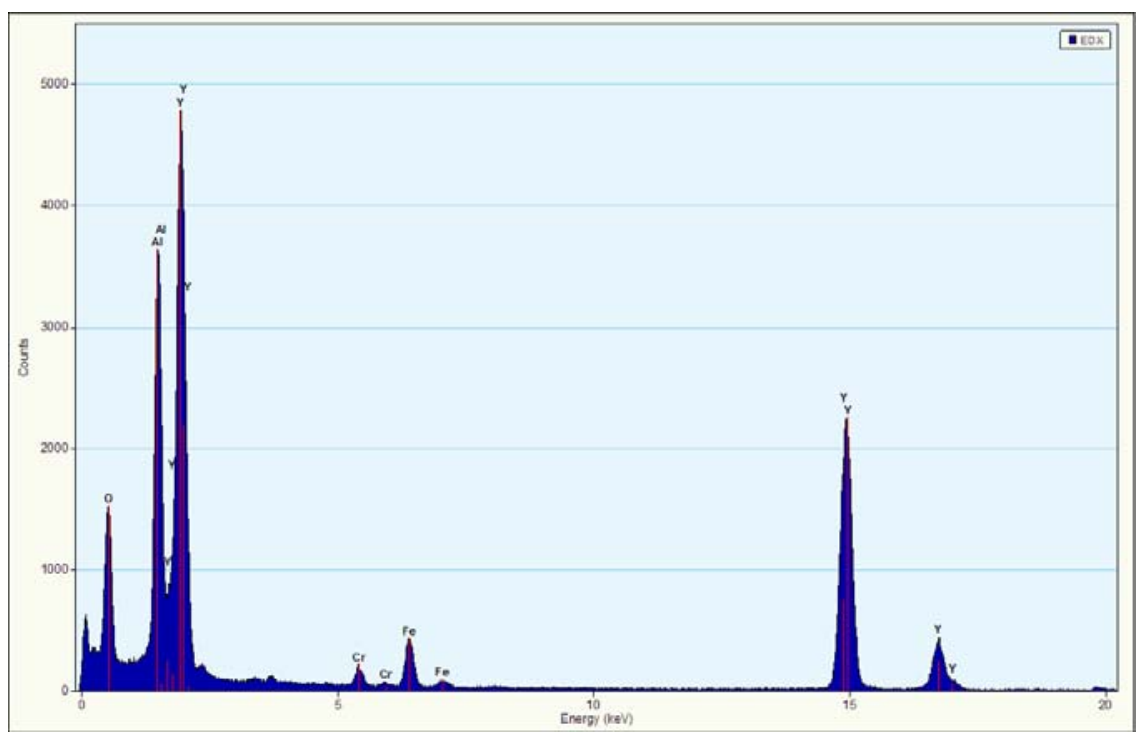

Fig. 13: Example of EDS analysis results of particles observed inside the grains in the stir zone. 
Table 2: EDS chemistry analysis of the stir zone in butt weld (at. \%)

\begin{tabular}{|c|c|c|c|c|c|c|c|}
\hline Position & Al & $\mathrm{Cr}$ & $\mathrm{Fe}$ & $\bar{Y}$ & $\mathbf{S}$ & $\mathrm{Ti}$ & Oxygen \\
\hline & \multicolumn{7}{|c|}{ HIGH YTTRIUM } \\
\hline 1 & 39 & 2 & 4 & 55 & $<.5$ & 0 & yes \\
\hline 8 & 36 & 3 & 11 & 48 & 1 & 9 & yes \\
\hline 10 & 38 & 2 & 3 & 57 & $<.5$ & 0 & yes \\
\hline 11 & 53 & 1 & 2 & 43 & 0 & 0 & yes \\
\hline 3 & 46 & 4 & 19 & 31 & 1 & 0 & yes \\
\hline \multirow[t]{2}{*}{5} & 69 & 1 & 7 & 21 & 2 & 0 & yes \\
\hline & \multicolumn{7}{|c|}{ LOW YTTRIUM, HIGH AL } \\
\hline 6 & 88 & 1 & 2 & 9 & 0 & 0 & yes \\
\hline \multirow[t]{2}{*}{7} & 99 & $<.5$ & 1 & 0 & 0 & & no \\
\hline & \multicolumn{7}{|c|}{ LOW Y, HIGH AL, MOD FE,CR } \\
\hline 12 & 62 & 8 & 25 & 4 & 0 & 0 & less \\
\hline 13 & 60 & 8 & 30 & 1 & $<.5$ & $<.5$ & less \\
\hline 14 & 39 & 13 & 48 & $<.5$ & $<.5$ & & less \\
\hline \multirow[t]{2}{*}{15} & 72 & 4 & 16 & 6 & $<.5$ & 1 & no \\
\hline & \multicolumn{7}{|c|}{ MATRIX } \\
\hline 2 & 6 & 21 & 71 & 0 & 1 & 0 & no \\
\hline 4 & 7 & 21 & 71 & 0 & 1 & 0 & no \\
\hline 9 & 4 & 24 & 70 & 0 & 2 & 0 & no \\
\hline
\end{tabular}

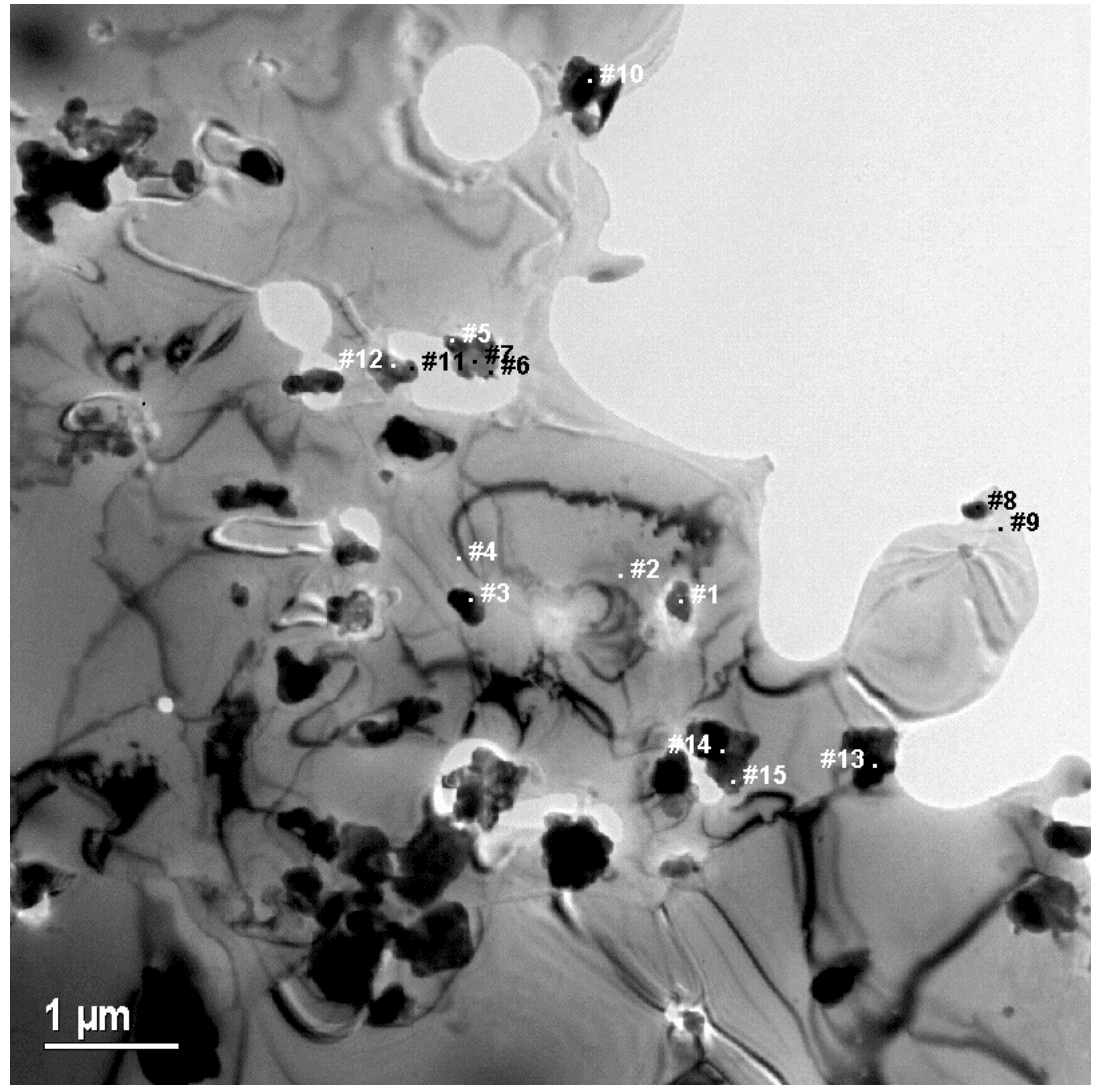

Fig. 14: Identification of locations for EDS micro-chemistry analysis of the butt weld stir zone 
Fig. 15 presents the microhardness distribution in the butt weld joint. Overall, the stir zone has a slightly lower microhardness than the adjacent base metal. However, noticeable hardness increases are observed in the severe deformation layer. The cause of such increase remains to be determined.
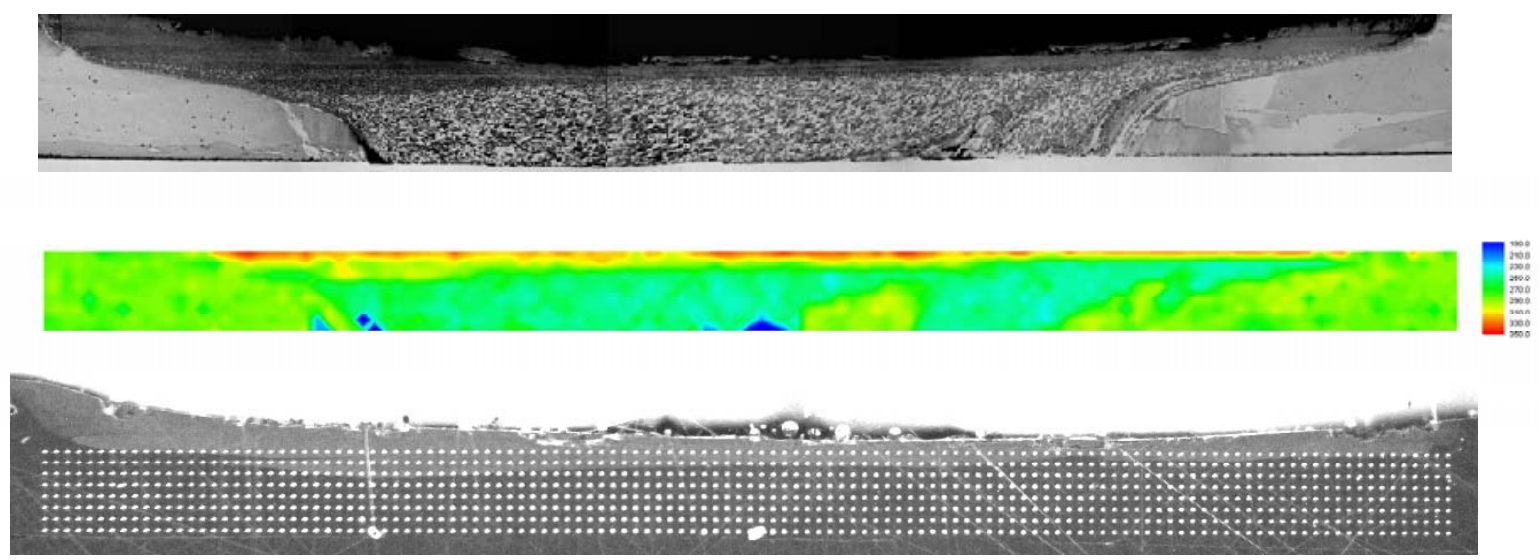

Fig. 14: Vicker's microhardness distribution in the stir region.

\section{SUMMARY AND FUTURE WORK}

Preliminary results in the present investigation can be summarized as follows:

(1) Friction stir welding of ODS alloy MA956 thin sheet is feasible. Fully consolidated solidstate bonding was produced for the butt joint configuration.

(2) Nano size yttrium oxide particles, the primary high-temperature strengthening phase in ODS alloys, were preserved in the weld region. This suggests the potential of the friction stir welding to join the ODS alloys without significantly affect their excellent hightemperature mechanical properties.

(3) Small, equiaxed grains were formed in the weld region as a result of dynamic recrystallization induced by thermoplastic deformation of the friction stir welding process. Post-weld heat treatment should be considered to restore the large grains.

(4) A slight decrease in microhardness of the stir zone was observed.

To further investigate the feasibility of ODS alloy welding using the friction stir welding process, the following $\mathrm{R} \& \mathrm{D}$ activities are suggested:

(1) Investigate the effects of post-weld heat treatment on the microstructure (grain size and oxide particle distribution) of the weld region. 
(2) Develop welding process for lap joint configuration.

(3) Test high-temperature mechanical properties of friction stir welds.

(4) Conduct more detailed microstructure studies to understand the changes in oxide particle morphology and size, as well as interactions between different oxide particles and their effects on high temperature strength.

\section{REFERENCES}

1. Hack, G. A. J., "Superalloys for the 80s", Metallurgia, Vol. 49, No. 6, pp. 256-257, June 1982.

2. Sha, W. and Bhadeshia, H. K. D. H., "Characterization of Mechanically Alloyed Oxide Dispersion-Strengthened Nickel-Base Superalloy MA760", Metallurgical and Materials Transactions A-Physical Metallurgy and Materials Science, Vol. 25, No. 4, pp. 705-714, 1994.

3. Fleetwood, M. J., "Mechanical Alloying-The Development of Strong Alloys", Materials Science and Technology, Vol. 2, No. 12, pp. 1176-1182, December 1986.

4. Chou, T. S. and Bhadeshia, H. K. D. H., "Grain Control in Mechanically Alloyed Oxide Dispersion-Strengthened MA-957 Steel”, Materials Science and Technology, Vol. 9, No. 10, pp. 890-897, 1993.

5. Shaw, M. T., "Incoloy Alloy MA956 for High Temperature Industrial Applications", Metallurgia, Vol. 54, No. 11, pp. S32-S33, November 1987.

6. Grundy, E.; Precious, C. J. and Finder, D., "Hot Forming of Mechanically Alloyed Gas Turbine Components", Metal Powder Reports, Vol. 40, No. 10, pp. 565-569, October 1985.

7. Fischer, J. J., "Properties of Mechanical Alloyed Super-alloy Related to Industrial Heating Uses”, Industrial Heating, Vol. 40, No. 12, pp. 25-26, December 1988.

8. Wilson, R. K. and Perry, F. L., "Superior Heat Treatment Capabilities of MA Superalloys Developed by Thermo-mechanical and Heat Treatment Processes", Industrial Heating, Vol. 51, No. 5, pp. 27-30, May 1984.

9. Klopp, W. D., Ferritic Stainless Steel (Non-Martensitic), FeNM-1450, MA956, Aerospace Structural Metals Handbook, Dec. 1992. 
INITIAL DEVELOPMENT IN JOINING OF ODS ALLOYS USING FRICTION STIR WELDING

10. Bucklow, I. A., Dunkerton, S. B. and Threadgill, P. L., "Investigation into the Joining of Creep-Resistant Oxide-Dispersion-Strengthened Alloys", research report of TWI, Oct. 1996.

11. Kelly, T. J., "Pulsed YAG (yttrium-aluminum-garnet) Laser Welding of ODS Alloys", Applications of Lasers in Materials Processing, Proceedings, Conference, pp. 43-50, Washington DC, 18-20 Apr. 1979.

12. Sketchley, P. D., Threadgill, P. L. and Wright, I. G., "Rotary friction welding of an $\mathrm{Fe}_{3} \mathrm{Al}$ based ODS alloy", Materials Science and Engineering A. Vol. A329-331, No. 7-12, pp. 756-762, 2002.

13. Shinozaki, K., Kang, C. Y., Kim, Y. C., Aritoshi, M., North, T. H., and Nakao, Y., "The Metallurgical and Mechanical Properties of ODS Alloy MA 956 Friction Welds", Welding Journal. Vol. 76, No. 8, pp. 289-299. Aug. 1997.

14. Kang, C. Y., North, T. H., and Perovic, D. D., "Microstructural Features of Friction Welded MA956 Superalloy Material", Metallurgical and Materials Transactions A. Vol. 27A, No. 12, pp. 4019-4029, Dec. 1996.

15. Ekrami, A., Khan, Han, T. I. and Malik, H., "Effect of Transient Liquid Phase Diffusion Bonding on Properties of ODS Nickel Alloy MA758", Materials Science and Technology, Vol. 19, No.1, pp. 132-136, Jan. 2003.

16. Moore, T. J. and Glasgow, T. K., "Diffusion Welding of MA 6000 and a Conventional Nickel-Base Superalloy”, Welding Journal. Vol. 64, No. 8, pp. 219-226. Aug., 1985.

17. Kleicker, J., "Diffusion Welding of ODS Alloys", DVS Berichte No.125. Brazing, High Temperature Brazing and Diffusion Welding, Proceedings, 2nd International Conference, Essen; 19-20 Sept. 1989. pp. 53-56, 1989.

18. Haufler, G. and Mayer, H. G., "Diffusion Bonding of ODS Materials", DVS Berichte No.125. Brazing, High Temperature Brazing and Diffusion Welding, Proceedings, 2nd International Conference, Essen; 19-20 Sept. 1989. pp. 137-140, 1989.

19. Stover, D., Buchkremer, H. P., Hammelmann, K. H. and Hecker, R., "HIP Diffusion Bonding of ODS Materials", Hot Isostatic Pressing: Theory and Applications, Proceedings, 2nd International Conference, Gaithersburg, MD, 7-9 June 1989. pp. 217222. 1991.

20. Markham, A. J., "The Diffusion Brazing of Nickel-Based Oxide Dispersion Strengthened Alloys", Thesis (Ph.D), University of Cambridge, Cambridge, CB2 1TN, UK; 1988.

21. Verpoort, C., Nazmy, M. and Jongenburger, C. P., "HIP - Diffusion Bonding of ODS MA 6000”, Isostatic Pressing - ISO 3, Vol. 1, Proceedings, 3rd International Conference, London; 10-12 Nov. 1986. pp. 32.1-32.28, 1986. 
22. Hammelmann, K. H., Buchkremer, H. P. and Stover, D., "HIP-Diffusion Bonding of ODS Materials by Use of Plasma Sprayed Encapsulation", Diffusion Bonding 2, Proceedings, 2nd International Conference, Cranfield; 28-29 Mar. 1990. pp. 250-260. 1991.

23. Kopf, M., Haufler, G., Mayer, H. G., Reheis, N. and Sporer, D., "Diffusion Bonding of a Ferritic ODS Superalloy with Different Materials", DVS Berichte, No.148. Brazing, High Temperature Brazing and Diffusion Welding, Proceedings, 3rd International Conference, Aachen; 24-26 Nov. 1992. pp. 50-53, 1992.

24. Bucklow, I. A., "Diffusion Bonding a Creep-Resistant Fe-ODS Alloy", Advances in Joining Newer Structural Materials, Proceedings, International Conference, Montreal, Canada, Paper II.13; 23-25 July 1990. pp. 299-304, 1990.

25. Rydstad, H. and Singer, R. F., "Mechanical Properties of Forge-Bonded MA 6000", Horizons of Powder Metallurgy, Part 2, Proceedings, International Powder Metallurgy Conference and Exhibition, The Future of Powder Metallurgy, P/M '86, Dusseldorf, West Germany; 7-11 July 1986. pp. 713-716, 1986.

26. Nishimoto, K., Saida, K. and Tsuduki, R., "Evaluation for Mechanical Properties of Pulsed Electric-Current Sintering Bonded Joint of ODS Alloys", Today and Tomorrow in Science and Technology of Welding and Joining, Proceedings, 7th JWS International Symposium (7WS), Kobe, Vol. 2, Paper IP1-2; 20-22 Nov. 2001. pp. 857-862. 2001.

27. Holmstrom, S., Heikinheimo, L., Siren, M. and Auerkari, P., "Brazing of an Iron Based ODS Alloy and Joint Performance and Structure", Welding in the World. Vol. 44, No. 5, pp. 15-19. Sept.-Oct. 2000.

28. Kelly, T. J., "Brazing of Oxide Dispersion Strengthened Superalloys", Brazing and Soldering, No. 6, pp. 21-24, 1984.

29. Kelly, T. J., "Joining Mechanical Alloys for Fabrication", Frontiers of High Temperature Materials II, Proceedings, Conference, London, Session III. Paper 1, 22-25 May 1983, pp. 20, 1983.

30. Kelly, T. J., "Brazing of Inconel Alloy MA754 for High Temperature Applications", Welding Journal. Vol. 61, No. 10, pp. 317-319, Oct. 1982.

31. Siren, M., Holmstrom, S., Heikinheimo, L. and Auerkari, P., "Brazing and Joint Properties of an Iron-Based ODS Alloy", DVS Berichte, No.192. Brazing, High Temperature Brazing and Diffusion Welding, Proceedings, 5th International Conference, Aachen; 16-18 June 1998, pp. 80-84, 1998. 
INITIAL DEVELOPMENT IN JOINING OF ODS

ALLOYS USING FRICTION STIR WELDING

32. O'Donnell, D., "Joining of Oxide-Dispersion-Strengthened Materials", ASM Handbook, Vol.6: Welding, Brazing and Soldering. Materials Park OH 44073, USA; ASM International, pp. 1037-1040, 1993.

33. Ambroziak, A. and Lison, R., "Welding and Brazing ODS Materials", Schweissen und Schneiden. Vol. 44, No. 7, pp. 371-376 (English translation of text and captions pp. E124-E126), July 1992.

34. Bucklow, I. A., "Joining a Ni-based Creep-Resistant (ODS) Alloy by Brazing”, Advances in Joining Newer Structural Materials, Proceedings, International Conference, Montreal, Canada, Paper II.12, 23-25 July 1990. pp. 293-298, 1990.

35. Jackson, P. W., Marsh, N. P., Hack, G. A. J. and Shaw, M. J., "Explosive Welding of ODS Incoloy alloy MA956”, Welding and Metal Fabrication. Vol. 58, No. 2, pp. 84-92. Mar. 1990.

36. Zirker, L. R., Bottcher, J. H., Shirakura, S., Tsai, C. L. and Hamilton, M. L., "Fabrication of Oxide Dispersion Strengthened Ferritic Clad Fuel Pins", Report to U. S. Department of Energy, ANL/CP - 72041, December, 1991.

37. Thomas, W.M., Nicholas, E.D., Needham, J.C., Murch, M.G., Temple-Smith, P. and Dawes, C. J., 'Improvements Relating to Friction Stir Welding', European Patent Specification 0615480 B1, 1991.

38. Mishra, R.S., "Friction Stir Processing Technologies," Advanced Materials \& Processing, Vol. 161, No. 10, 43-46, 2003.

39. Midling, O. T., "Material Flow Behavior and Microstructural Integrity of Friction Stir Butt Weldments," Proceedings of the Fourth International Conference on Aluminum Alloys (ICAA4), Atlanta, GA, 1994.

40. Ren, W., and Feng, Z. "Development of Oxide-Dispersion-Strengthened Welds for High Temperature Creep Resistance", proposal submitted to Gen IV Nuclear Reactor Materials Program, Ultra Supercritical Steam Boilers Program, Nuclear Fusion Program, Metals and Ceramics Division, Oak Ridge National Laboratory, August 5, 2004.

41. INCOLOY Alloy MA956, Special Metals. www.specialmetals.com, 2004.

42. Aerospace Structural Metals Handbook, 1992.

43. Fisher,J. J., Astery, I. and Morse, J. P., in "Superalloys: Metallurgy and Manufacturing", B.H. Keat ed., Claitor's Publishing Division, Baton Rouge, LA, 1976, pp. 361-73. J.D. Whittenbergy, Metall. Trans. A, vol. 9A, 1978, pp. 101-10. 


\section{Distribution}

1. T. D. Burchell

2. W. R. Corwin

3. S. R. Greene

4. Z. Feng

5. D. T. Ingersoll

6. Y. Katoh

$7 . \quad$ J. W. Klett

8. E. Lara-Curzio

9. L. K. Mansur

10. T. E. McGreevy

11. R. K. Nanstad
12. R. A. Raschke

13. W. Ren

14. P. L. Rittenhouse

15. A. F. Rowcliff

16. L. L. Snead

17. R. G. Stoller

18. R. W. Swindeman

19. P. F. Tortorelli

20. D. F. Wilson

21. S. J. Zinkle

22. Trevor Cook, NE-20/Germantown Building, Office of Advanced Nuclear Research, U.S. Department of Energy, 1000 Independence Avenue, S.W., Washington, DC 20585-1290

23. Susan Lesica, NE-20/Germantown Building, Office of Advanced Nuclear Research, U.S. Department of Energy, 1000 Independence Avenue, S.W., Washington, DC 20585-1290

24. Thomas J. O'Conner, NE-20/Germantown Building, Office of Advanced Nuclear Research, U.S. Department of Energy, 1000 Independence Avenue, S.W., Washington, DC 20585-1290

25. David Ostby, Idaho National Engineering and Environmental Laboratory, P.O. Box 1625, Idaho Falls, Idaho 83415-3750

26. Rafael Soto, Idaho National Engineering and Environmental Laboratory, P.O. Box 1625, Idaho Falls, Idaho 83415-3750

27. Robert Versluis, NE-20/Germantown Building, Office of Advanced Nuclear Research, U.S. Department of Energy, 1000 Independence Avenue, S.W., Washington, DC 205851290

28. Kevan Weaver, Idaho National Engineering and Environmental Laboratory, P.O. Box 1625, Idaho Falls, Idaho 83415-3750 